III-2 | 2011

Pragmatism and the Social Sciences. A Century of Influences and Interactions, vol. 1

\title{
American Social Science
}

The Irrelevance of Pragmatism

Peter Manicas

\section{(2) OpenEdition}

Electronic version

URL: http://journals.openedition.org/ejpap/814

DOI: 10.4000/ejpap.814

ISSN: 2036-4091

Publisher

Associazione Pragma

Electronic reference

Peter Manicas, « American Social Science », European Journal of Pragmatism and American Philosophy [Online], III-2 | 2011, Online since 29 December 2011, connection on 19 April 2019. URL : http:// journals.openedition.org/ejpap/814 ; DOI : 10.4000/ejpap.814

This text was automatically generated on 19 April 2019

\section{c) (†) $९$}

Author retains copyright and grants the European Journal of Pragmatism and American Philosophy right of first publication with the work simultaneously licensed under a Creative Commons AttributionNonCommercial-NoDerivatives 4.0 International License. 


\title{
American Social Science
}

\author{
The Irrelevance of Pragmatism
}

\author{
Peter Manicas
}

\section{Introduction}

1 This essay argues that, contrary to a good deal of received opinion, the classical pragmatists, C.S. Peirce, William James and John Dewey, had almost no influence as regards the human sciences in the United States, and that in a stunning inversion, their distinct views were absorbed by the mainstream and employed to justify mainstream practices. Thus, for example, in her extremely well documented The Origins of American Social Science (1991), Dorothy Ross quite correctly characterizes American social science as "scientistic." But she also argues that pragmatism and especially Dewey was a critical ally in the American construction of the social sciences. ${ }^{1}$ The confusions here will take some unpacking.

2 Broadly, my argument is this: We need to see, first, that the idea of science cannot be taken for granted. Through the work of a host of late 19th century philosopher/ physicists, a positivist conception, originally put forward in 1830 by August Comte, won out. It was powerfully fleshed out in the 1930s by Vienna logical empiricism and became hegemonic. ${ }^{2}$ The classical pragmatists were well aware of this historically critical development. Their pragmatisms were, indeed, self-conscious efforts to provide an alternative conception.

3 Second, since the disciplines of the human sciences are not natural kinds but are socially constructed by agents working with materials at hand, we need to provide at least a sketch of a sketch of this construction. Writing prior to World War I, Thorstein Veblen clearly understood what was going on. "Given the exigencies of competitive enterprise in America," with "business men" as executives of the new universities, there was little choice but to reward those who enhanced the position of the university in the larger community. The result is "a 'science' of complaisant interpretations, apologies, and projected remedies” (1957: 136). 
Third, after considering the views of Peirce and James against the background of then current understandings of science, I develop Dewey's largely unacknowledged and frequently misunderstood criticism of the genesis of positivist academic psychology and social science. ${ }^{3}$

\section{What is Science?}

In what became a stunningly prophetic conception, Comte had provided a clear definition of positivism, the "stage" of mind which follows the "theological" and the "metaphysical."

6 First, following Kant, he insisted that "metaphysical" and "fictitious" ideas were no part of science. These included references to causes as productive powers, essences, first and final causes and non-observable "forces." For the positivist, then, science is empirical in the sense that it deals with ideas that can be verified (or falsified) by appeal to experience. To be sure, there are problems in seeing exactly what counts as verifiability (falsifiability) - problems that have haunted all recent empiricist theories of science.

7 Second, Comte argued that we should give up the search for causes in exactly the sense that causes are productive powers. We should seek causes in Hume's sense: that is, as "invariable relations of succession and resemblance." On this view, we cannot observe (say) the productive power of opium or for that matter, of gravity. We see rather a constant relation of succession: if one takes opium, one sleeps: Bodies near earth fall at D $=16 \mathrm{t} 2$.

Third, following on the foregoing and most critically, the explanation of facts is simply a deduction of an instance from general laws. Thus, on what is now called "the DeductiveNomological" model, "explanation" and prediction (what Comte called "prevision") are symmetrical: Having the law allows us to "explain" as well as to predict.

These ideas lay more or less fallow until the last decades of the 19th century when, with the advance of chemistry, the culmination of classical physics and the development of industrialized science, the precise nature of a genuine science became a critical problem, hotly debated by an eminent group of philosopher/physicists in Germany, France and England.

G. R. Kirchhoff's Principles of Mechanics (1874), Ernst Mach's Science of Mechanics (1883), and Wilhelm Ostwald's General Chemistry (1888) were among the first blasts to ward establishing a stringently anti-metaphysical empiricist philosophy of science. ${ }^{4}$ These writers were joined by Ludwig Boltzmann and Heinrich Hertz in Germany, by Pierre Duhem and Henri Poincaré in France, and in England by W. K. Clifford and, following the path of Mach, by Karl Pearson. Thus, Mach and Duhem, took the deductivist view of explanation to its logical conclusion and held that science does not even try to explain; it only describes. Writing in 1906, Pierre Duhem offers that "to explain [...] is to strip reality of the appearances covering it like a veil, in order to see bare reality itself," but this is metaphysics. For him, "A physical theory is not an explanation. It is a system of mathematical propositions deduced from a small number of mathematical principles, which aim to represent as simply, as completely, and as exactly as possible a set of experimental laws." "Science," now cleansed of "pre-scientific" metaphysics, could claim unchallengeable authority. 


\section{The Disciplinary Development of the Social Sciences}

11 Unlike pears and porcupines, the disciplines of the social sciences are not "natural kinds": They exist only by virtue of beliefs and practices created by historical agents working with materials at hand. And their social construction began in earnest in America only some one hundred years ago. ${ }^{6}$ The question of the nature of the human sciences remained open with at least four competing conceptions; a positivist view and three different contestations of positivism: a "Marxist" view originating with Engels, and the very different anti-positivisms of Dilthey and Weber. ${ }^{7}$ It is easy to show why, given the opportunity, the disciplines were constituted in positivist terms. Marxism was (and remains?) anathema in the Universities of the "Free World"; Dilthey and Weber were substantially unknown in the US and while both did develop positions which rejected the "natural science" model - understood as a positivism - neither had the distinct advantages of the positivist image of natural science, in particular the authority which the mature natural sciences were then generating.

12 A persistent assumption of disciplinary histories of the social sciences is the idea that each of the main branches of today's social sciences reflects at least reasonably firm strata of the social world. There is, thus, a "natural" division of labor that was finally realized with the maturation of the distinct social sciences. Explaining the emergence of the disciplines, then, takes the form of showing how pathfinders, interested in constituting analogues to the successful modern natural sciences, broke from the "prescientific" past and established restricted domains for controlled inquiry. Each story is different, of course, and some are stormier than others. Some, for example psychology, are even less settled than others.

13 I give here but a hint of the key moves and players. At least in broad terms, it is easy to identify the historical process which generated the beliefs and practices which constituted disciplinary social science. Two changes of enormous importance were critical to the American institutionalization of the social sciences. First were the new problems created by very rapid industrialization: immigration, urbanization and "the social problem." Second, usually ignored, was the creation of the modern "research" University, an American innovation on German practice. Universities, of course, had existed in Europe for centuries, but as many observers have noted, "the true ancestor's of today's universities are certainly not their medieval precursors." Similarly, America had "colleges" but the curriculum was "medieval" and culminated in "moral philosophy," frequently taught by the President, who was often a cleric. There was no graduate curriculum. Sensitive to their backwardness, but even more sensitive to the potential new roles that a University could play, academic entrepreneurs, working closely with the Rockefellers, Carnegies and Vanderbilts, built what was needed. Shored up by carefully directed violence, racist politics could easily be joined to the politics of economic growth and, in turn, both could be joined to technocratic solutions - solutions to be provided by "experts" As Bledstein put it, "Americans lacked tradition as a source of authority, but they did "not lack 'science.."

Indeed, was social inquiry to be left to the "metaphysical philosophers," the likes of Henry George, or to dilettantish reformers like Jane Addams or W. E. B. DuBois, or to irresponsible journalists, like Jacob Riis? Surely social problems were as amenable to scientific solutions as any other. And surely, if social scientists were to be professionals, 
they had to mark out their own scientific territory and establish their own system of credentialing. Academic departments, the $\mathrm{PhD}$, professional associations and journals would provide exceptionally efficient means, then as now, for controlling the curriculum.

The first critical conceptual move was the divorce of history and the social sciences. This process, which required de-Germanization and de-historicism, was to take two generations beginning with creation of graduate programs in the social sciences, Columbia's School of Political Science, established under John Burgess in 1880, and Herbert B. Adams's Graduate Program in Historical Studies at Hopkins. As regards Political Economy, America had a version of the Methodenstreit, between Richard Ely, inspired by the Verein für Sozialpolitik, and Simon Newcombe, an able and articulate spokesman for the abstract deductivist conception of political economy which Ricardo had inspired and which J.S. Mill had tried to restrict. John Bates Clark's original integration of the new marginalism effectively "answered" the socialists and singletaxers and was an important part of the ideological battle which had to be fought. Veblen was on the other side, offering Peircean criticisms of the new marginalism..$^{10} \mathrm{~A}$ consequence of the American battle over the nature of political economy, impelled by wholly independent institutional factors, was the opportunity provided to the "political scientists" to establish "government" as their domain and to Franklin H. Giddings and E. A. Ross, one of the first of Ely's Wisconsin Ph.D.'s, to capture the residue under the heading of an autonomous scientific sociology.

Giddings, the founder of the Colombia School of Sociology, had been reading Mach and Pearson and was convinced by their arguments that in eschewing metaphysics, science was actually descriptive rather than explanatory. "All science knew was the description of concomitant and co-varying facts" (Quoted by Ross 1991: 238). Accordingly, statistical methods were the "heart and soul of a scientific sociology." Charles Merriam's clarion call of 1921, "The Present State of the Study of Politics," was even clearer in seeing the connection between positivist epistemology and Comte's commitment to "prevision and control." Thus, he writes that with a scientific politics which quantified data and identified "relations of variables," it would be possible to have "a more intelligent control of the process of government" (Quoted by Somit and Tanenhaus 1967: 11).

World War I was decisive in the victory of positivist social science. In a stunning consensus, American social scientists enthusiastically encouraged American entry into the war and then enthusiastically cooperated with the government in realizing America's self-defined mission "to make the world safe for democracy." For Anglo-Americans, the defeat of Germany represented, as well, the defeat of "metaphysical," "statist," historical and holistic German social science. Long suspicious of it in any case, the war proved to them that older British and French empirical philosophies, continuously represented in the "old" political economy and in British utilitarian theories of government, had been right all along.

Herbert Hoover's 1929 gathering of a distinguished group of social scientists "to examine the feasibility of a national survey of social trends" well marks the beginnings of the contemporary vision of social science. Funded by the Rockefeller Foundation with the full support of the Social Science Research Council and the Encyclopedia of the Social Sciences, four years of work by hundreds of inquirers resulted in "The Ogburn Report," 1600 pages of quantitative research. Pitirim Sorokin, who had no problems with the appropriate use of statistics, observed: 
In the future some thoughtful investigator will probably write a very illuminating study about these 'quantitative obsessions' [...] tell how such a belief became a vogue, how social investigators tried to 'measure' everything; how thousands of papers and research bulletins were filled with tables, figures, and coefficients; and how thousands of persons never intended for scientific investigation found in measurement and computation a substitute for real thought. ${ }^{11}$

Thenceforth, "researchers" could produce many tons of "findings," and there would be little danger that any of it would bear any "colour of iconoclasm."

\section{Classical Pragmatism}

What of the pragmatists? By the turn of the century, it was clear to James, Veblen and Dewey that science was giving "its tone to modern culture." But for them, the consequences were more than uncertain. The most well-known advocates of science, Spencer, Clifford, Huxley and others, were not only defending agnosticism and positivism, but a view in which science was to be immunized from the biases and interests of human communities. James, Veblen and Dewey were anything but enthusiastic about the situation as they saw it. Indeed, James's criticisms hinged on ideas about the foundations of science which were completely novel, and Veblen and Dewey were clearest in seeing that science was being shaped by changes "in industry and in the economic organization of society." Science, pretender to transcendent authority, was becoming industrialized, technocratic.

21 David Hollinger has rightly argued that the critical role played by the pragmatists in American culture was "to find and articulate" a "way of life consistent with what they and their contemporaries variously perceived as the implications of modern science" (Hollinger 1985: 93). It is widely held, by friends and enemies, that they succeeded. On this interpretation, the pragmatists adopted a view of science in which successful prediction and control vindicated inquiry. By subordinating all inquiry to "practical ends," they could show that a belief was warranted only insofar as it was "scientific." Finally, they could then vindicate a culture whose "social motor" was science. In what follows, I suggest that the foregoing interpretation is a stunning distortion and that the pragmatists failed utterly in their quest to set a new course for a "scientific" civilization. Not only were the forces at work resistant to their criticisms, but their fundamental insights, in a paradoxical inversion, became absorbed in distorted forms.

Peirce, James and Dewey sought a conception of philosophy which responded to the "scientism" of the dominating view of science. Peirce wrote before disciplinary social science was created and so we will not find anything from him on the topic. But he was fully aware of work of the philosophers/physicists who had articulately a powerful positivist conception of natural science. And did not like it. The focus here is on his views of the causal importance of the independently existing world of nature.

\section{Peirce's Pragmatism}

As everyone knows, what came to be called "pragmatism" was first set out by Peirce in two remarkable essays published in Popular Science Monthly in 1877-78. In the first, "The Fixation of Belief," he put forward his genuinely original "doubt-belief" theory of inquiry, what I shall take to be the core of "pragmatism." Insisting that "that sole object of inquiry 
is the settlement of opinion" - not as the tradition had held, the securing of truth, and that "belief is of the nature of a habit," he offered that of the possible modes of fixing belief, while all "do have their merits," the method of science had, finally, to be the one we must chose, exactly because the method of science alone "presents any distinction of a right and a wrong way" (108-9). Its "fundamental hypothesis" is that there are real things, whose characters are entirely independent of our opinions about them; these realities affect our senses according to regular laws, and, though our sensations are as different as our relations to objects, yet, by taking advantage of the laws of perception, we can ascertain by reasoning how things really are (107-8).

Peirce cannot "prove" that there is something "which affects or might affect every [one]", but "upon which our thinking has no effect." Yet there is no reason that a genuine doubt should arise in the practice of the method; indeed, "nobody [...] can really doubt there are realities, or, if he did, doubt would not be a source of dissatisfaction" (Peirce 1950: 108). We can know "how things really are" even if the effects of reality on us "are necessarily as various as are individual conditions." We can because we can assume that there are "regular laws" involved in our transacting with "real things". Finally, not only does "everybody use the method," hesitating only when "he does not know when to apply it," but "scientific investigation has had the most wonderful triumphs in the way of settling opinion" (108).

This enormously rich beginning was followed by "How to Make Our Ideas Clear," the essay which contains Peirce's famous "pragmatic maxim."

Peirce illustrated his famous principle by asking if one could say of a diamond that had been crystalized in the midst of a cushion of cotton and had remained there until it was burned up, whether it was really hard? The issue was not merely whether unscratched diamonds are hard, but more generally, there was the question of that Reality which he had posited as so essential to the method of science. When Peirce applied his principle to the meaning of "the real," he was led, as everyone knows, to assert that "the opinion which is fated to be ultimately agreed to by all who investigate is what we mean by the truth, and the object represented in this opinion is the real" (133). Against himself, he asked whether this was consistent with the definition given in his fixation essay? Did it not, in idealist fashion, make "the characters of the real depend upon what is ultimately thought about them." He answered that "reality is independent, not necessarily of thought in general, but only of what you or I or any finite number of men may think about it" (133).

But if "the real" is to provide a constraint on current belief adequate for epistemic purposes, will this do? In The Monist of 1905, he returned to these problems. In the first of two essays, he made clear that "instead of merely jeering at metaphysics, like other prope-positivists, the pragmaticist extracts from it a precious essence, which will serve to give life to cosmology and physics" (Peirce 1950: 192). This "precious essence" was his "scholastic realism" - and precious it indeed was. But if pragmatism was "propepositivist," what did this mean? Peirce was as emphatic about his scholastic realism as he was emphatic about what for him was the real novelty of the new pragmatic theory: "its recognition of an inseparable connection between rational cognition and rational purpose," the connection which James will be so pleased to develop.

Whatever Peirce intended by his scholastic realism, it is clear enough that it is inconsistent with all the positivisms, Comte's, Mill's, Mach's or later Vienna varieties. 
While for Peirce, there was a "non-experienceable reality" - in this he agreed with Kant "there are real objects that are general, among the number being the modes of determination of existent singulars." The article of 1878 had either glossed over this point as "unsuited" to the public there addressed or, he noted, "perhaps the author wavered in his own mind" (215). In that essay, he had written: "it would be merely a question of nomenclature whether that diamond should be said to have been hard or not." This is, he now writes, no doubt true, "except for the abominable falsehood in the word 'merely,' implying that symbols are unreal." "Nomenclature involves classification," he continued, "and classification is true or false." Thus, "the generals to which it refers are either reals [...] or figments" (215). In this case, the "generals" are real:

There are diamonds and anything which is really a diamond is really hard because being hard is an inseparable property of at least some of those other properties which make a diamond what it really is. It must be hard. (219)

The point must not be missed. On positivist versions, laws of nature are construed as universal conditionals of the form $(\mathrm{x})(\mathrm{Fx} \rightarrow \mathrm{Gx})$ where ' $\rightarrow$ ' is "suitably" interpreted. That is, a law is construed as a contingent relationship between the extensions of its terms, "all F's are G's." But on Peirce's view of the matter, a law expresses a nomic relationship between properties, between F-ness and G-ness, properties to which we refer with corresponding abstract terms. The reality of the diamond is expressed in the truth of "general conditional propositions," but these are not construed in a Humean fashion, for as Peirce saw (and Kant before him), on such a view, science is not possible.

In an unpublished manuscript, "Laws of Nature and Hume" (1901), Peirce's criticism of Hume (and the Humeans) is decisive. He writes:

we do not say that the alternation of day and night is necessary, because it depends upon the circumstance that the earth continually rotates. But we do say that by virtue of gravity every body near the surface of the earth must be continually receiving a component downward acceleration [...] Nor do Hume or his followers dream of denying that. But what they mean when they say there is not "necessity" in gravitation is that every "event" which gravitation formulates is in reality totally independent of every other; just as Hume supposes the different instances of induction to be independent "evidences." One stone's falling has no real connection with another's fall [...] The objection to Hume's conception of a Law of Nature is that it supposes the universe to be utterly unintelligible, while, in truth, the only warrant for any hypothesis must be that it renders phenomena intelligible. (Peirce 1950: 310)

Science needs real connectedness; but such connectedness is not the product of constitutive features of the mind, as Kant had it. Connectedness is in the mindindependent world. It is thus that for Peirce, there are "objective possibilities," unactualized, but real. And thus also that for Peirce's pragmatism, intelligibility, not prediction is the only warrant for a hypothesis.

\section{James' Psychology and Philosophy of Science}

James's Principles is perhaps one of the two or three greatest books in the history of psychology. Yet contrary to the conventional wisdom, it had practically no influence on the development of American psychology. ${ }^{12}$ We can notice, first, that Principles was published when the subject-matter and method of psychology as a science were still very much unsettled (Manicas 1987, Chapter 9). 

位 in his "The Place of Science in Modern Civilization." In contrast to the "proximate laws of nature," scientific theories have to harmonize with the "proximate laws of nature," yet they are tested not in the course of everyday experience, but in "artificial experiments in the laboratory." James seems to see that, in order to set up an experiment, we need to "conjecture" that there is some unobservable mechanism whose processes have predicted effects. We contrive the experiment, then, so as to eliminate conditions that, in uncontrolled common experience, would interfere with its uncomplicated operation. That is, uncritical "experience," in Baconian fashion, does not "engender" the "inner relations." Rather, in experimentation, we generate experiences which give us evidence of the reality postulated by the theory.

Accordingly, what is pertinent to defining success will differ as well. Practical purposes offer practical tests; the interests of theoretic rationality, the "constructions" which bring "a strong feeling of ease, peace, rest," the "lively relief" which comes with "rational comprehension", answer to "the aesthetic Principle of Ease" (James 1978: 35), what Veblen termed, "the test of dramatic consistency." This is hardly an expression of the 
crude "cash value" pragmatism so frequently attributed to James and more generally to pragmatism!

In Principles, James's selected example is a long text from Helmholtz's Die Efhaltung der Kraft. Helmholtz had it right:

Theoretical science tries to discover the unknown causes of processes from their visible effects; tries to understand them by the law of causality [...] The ultimate goal of theoretical physics is to find the last unchanging causes of the processes of nature. (1981 II: 1261)

To be sure, James gave this a novel twist: "What makes the assumption [of unchanging causes] 'scientific' and not merely poetic, what makes a Helmholtz and his kin discoverers, is that the things of Nature turn out to act as if they were of the kind assumed" (1261). Over metaphysics, aesthetics and moral philosophy, science has an advantage:

Though nature's materials lend themselves slowly and discouragingly to our translation of them into ethical forms; but more readily into aesthetic forms; to translation into scientific forms they lend themselves with relative ease and completeness. The translation, it is true, will probably never be ended. The perceptive order does not give way, nor the right conceptive substitute for it arise at our bare word of command. It is often a deadly fight. (1981 II: 1236)

This is perhaps the basis of James's most profound ethical claim, repeated in many different formulations, that "the inmost nature of [...] reality is congenial to powers which [we] possess." Moreover, saying that "the translation [...] will probably never be ended" suggests that James would reject, as I think he should, the Peircean notion that in the end, there will be some one true "description" that is the product of persistent inquiry. Indeed, this would seem to be the case, as well, as regards ethical and aesthetic matters. Yet, the belief that there are "atoms and molecules moving to and from each other according to strange laws" is a belief about the nature of a hidden reality. Indeed, in his notes for the 1879 "The Sentiment of Rationality," there is a brilliant argument for the pragmatic pertinence of the idea of a non-experienceable reality. James says:

The principle of "pragmatism" which allows for all assumptions to be of identical value so long as they equally save the appearances will of course be satisfied by this empiricist explanation [...] [viz.], as according to Mill, that no mysterious "outness" needs to be postulated]. But common sense is not assuaged. She says, yes, I get all the particulars, am cheated out of none of my expectations. And yet the principle of intelligibility is gone. Real outness makes everything simple as the day, but the troops of ideas marching and falling perpetually into order, which you now ask me to adopt, have no reason in them - their whole existence is de facto and not de jure. (James, 1978: 374)

41 Nevertheless, if British phenomenalism did not suffice, neither could he accept a "more" beyond the actual as it functioned in Spencer and Kant. Appealing to Peirce's arguments, he first notes that "most scientific readers of Spencer wholly fail to catch the destructive import of his theory [...] They are willing to believe with the Master that the deepest reality is the absolutely irrational, because that reality is unknowable, but few of them ultimately realize that the knowable of their philosophy forms a world of Chance pure and simple" (1978: 369). Spencer's "unknowable" cannot function to give order, since to do this it must be known to have properties which could explain the orderliness of experience. It was thus that the "plus ultra in many philosophies - in Mr Spencer's and in Kant's e.g., the noumenon is a dog in the manger, it does nothing for us itself but merely stands and blasts with its breath the actual" (371). 
James was haunted by the apparent intractability of making sense of a relation between "outer" and "inner," between mental facts and facts in the world independent of mind. At this point at least, none of the inherited forms of phenomenalism would suffice, even if with it he would later change his mind. James agreed here with Peirce that the real could not be reduced to the actual: "There are still other forces at work in the mind which lead it to suppose something over and above the mere actuality of things." These include "the sense of futurity, the power of expectation" and our moral judgments, which "also involve [...] the notion of something related to the instant representation and yet lying beyond its mere actuality" (369-70).

The "Sentiment of Rationality" is important in another way. In holding that "conceptions, 'kinds' are teleological instruments," serving the needs of "theoretic rationality," he hinted at an utterly novel solution to some age-old problems, problems given a full-blown naturalistic treatment in Principles. On this view, classification, judging and predicating presuppose "a rather intricate system of necessary and immutable ideal truths of comparison." The "empiricists" are wrong in supposing that necessary truths are merely the result of "experience" or as Spencer had it, of "mere paths of 'frequent' association which outer stimuli [...] ploughed" into the brain. But the apriorists are also wrong since the "eternal verities" which "our mind lays hold of do not necessarily themselves lay hold on extra-mental being, nor have they, as Kant pretended later, a legislating character even for all possible experience." Rooted "in the inner forces which make the brain grow," and therefore not transcendental, they can be given a wholly naturalistic explanation. Moreover, psychology shows that classification is functional in the sense that essential attributes are nothing more than abstracted properties which serve inference.

It is not surprising, accordingly, that if Mill et al. "begin with a clear nominalist note, they are sure to end with a grating rattle which sounds very like universalia in re, if not ante rem " (James 1978: 49). As Peirce had already insisted, if "particulars" are wholly independent, inference is impossible. But on James's view, Peirce's "generals" did not need to have ontological status, either ante rem or in re. "The only meaning of essence is teleological [...] classification and conception are purely teleological weapons of the mind" (1981, II: 961).

Yet it is critical to see also that James's "pragmatic" account presupposes - as he sees that there are relatively enduring "things," that "the world" which is independent of mind is not Heraclitean: "This world might be a world in which all things differed, and in which what properties there were ultimate and had not farther predicates." Fortunately, our world "plays right into logic's hands. Some of the things [...] are of the same kind as other things; some of them remain always of the kind which they once were; and some of the properties of them cohere indissolubly and are always found together" (1981, II: 1246-7). That is, as Peirce had insisted, the "objects" of the external world have some "character" or other, even though they need not be self-identifying to be cognized. If they are not self-identifying, however, the way they got identified can be largely a function of human purposes, generically understood. H2O is not "more deeply and truly" the essence of water than it is "a solvent of sugar or a slaker of thirst" - since, as Dewey would later insist, "it is all of these things with equal reality" (II, 961, note). Still, for scientific purposes, H2O is primary, exactly because the scientific interest is "the interest of theoretic rationality."

The foregoing shows, I believe, that James offered a powerful philosophy of science which was not vulnerable to the difficulties in Peirce's more speculative view. And it was not a 
positivism: "All ages have their intellectual populace. That of our own day prides itself particularly on its love of Science and Facts and its contempt for all metaphysics" (1978: 56). Positivists fool themselves if they suppose that they dispense with metaphysics. Indeed, "Metaphysics of some sort there must be. The only alternative is between the good Metaphysics of clear-headed Philosophy and the trashy Metaphysics of vulgar Positivism" (57). James's philosophy of science - in many ways akin to contemporary critical realism, was no "trashy metaphysics of vulgar Positivism."13

But James believed that his Principles had failed to solve the mystery of knowing (James 1894), and, remarkably, after struggling for some twelve years to write his great book, James concluded that it was "a loathsome, distended, tumified, bloated dropsical mass, testifying to nothing but two facts: 1st, that there is no such thing as a science of psychology, and 2nd, that W. J. is an incapable." ${ }^{14}$

We must dismiss James's self-deprecation. But could he be right: There is no such thing as a science of psychology? This was, be sure, the last thing that the heirs of Wundt, the functionalists and behaviorists wanted to hear. The long-lived Dewey was at the founding of disciplinary psychology, but unlike James, he was in continuous dialogue with what it was to become. After Watson, Dewey seems to have lost all hope that psychology could become what he had hoped for. Indeed, he would find what he had hoped for in his Logic.

\section{Dewey and the Origins of American Psychology}

One of Dewey's earliest essays was an examination of "The New Psychology" (1884). Historians agree that "the new psychology" derived from Wilhelm Wundt who founded the first psychological laboratory in 1879 and whose Grundzuge der physiologische Psychologie (1st Edition, 1873) was an enormous success. But Wundt's psychology was complicated and offered many not always clearly consistent strands. But, according to Dewey, advances in the biological sciences have had another direct effect on the new psychology:

To biology is due the conception of organism [...] In psychology this conception has led to the recognition of mental life as an organic unitary process developing according to the laws of all life, and not a theater for the exhibition of independent autonomous faculties, or a rendez-vous in which isolated, atomic sensations and ideas may gather, hold external converse and then forever part. (EW 1:56)

This, of course, is directed at British-style associationist psychology, but as part of this, Dewey, still the Hegelian, endorses an ecological conception and the Wundtian premise that mind is social. Thus, "the idea of environment is a necessity to the idea of organism, and with the conception of environment comes the impossibility of considering psychical life as an individual, isolated thing, developing in vacuum" (ibid.).

But there is more. As a "movement," the new psychology has certain general features: "The chief characteristic distinguishing it from the old psychology is undoubtedly the rejection of a formal logic as a method and test. The old psychologists almost without exception held to a nominalist logic" (58), a pronounced tendency, especially among those "who proclaimed that 'experience' was the sole source of all knowledge" (59). Hume destroyed all relations except as "accidents" and "denied all universality". But he did this on the basis of "purely logical models," "abstract principles of difference and identity [...] put in the guise of psychological expression." The reaction to this, as in Kant, was to "fall back on certain ultimate, indecomposable, necessary first truths immediately known 
through some mysterious faculty of mind [...] Such intuitions are not psychological; they are conceptions bodily imported from the logical sphere" (ibid.). These criticisms of the prevailing alternatives are, of course, familiar Deweyan themes, and indeed, they hold against a wide variety of empiricisms from Quine to contemporary AI theory.

Dewey's hopes for "the new psychology" were not restricted to psychology only; he believed that it held enormous promise for philosophy itself. To be sure, not any psychology will do. Dewey's first effort was his 1886 Psychology, published four years before James's Principles of Psychology. Dewey intended the book to be an introductory text in psychology, but wanted also that it be an introduction to philosophy. In "Kant and Philosophic Method" (1884), Dewey challenged the "method of 'intellectualism' begun by Descartes" (EW: 1: 34) and he argued, as before, that Humeans, avowedly empirical, distorted experience. Kant's attempted repair had failed:

Though the categories make experience, they make it out of foreign material [...] They constitute objects, but these objects are not such in universal reference, but only to beings of like capacities of receptivity as ourselves. They respect not existence in itself, but ourselves as affected by that existence. (39)

Again, "the only conception adequate to experience as a whole is organism," a conception which Dewey found in Hegel's Logic $(42,43)$.

Before the century ended, Dewey did become uncomfortable with his Hegelianism, abandoning it for the variety of naturalism which now so strongly identifies him, but it is essential to see that while he abandoned Hegel and psychology, he never did abandon the seminal psychological insights that his Hegelianism afforded.

\section{Pragmatism and Functionalism}

In all the standard histories, "functionalism," the distinctive American psychology, figures heavily in subsequent development. Moreover, the "pragmatists" figure heavily in the development of "functionalism," from its beginnings in Chicago to its variant forms elsewhere. In these histories, the path from "functionalism" to "behaviorism" is less clear, even if Dewey, as the mentor to Angell, Watson's dissertation supervisor and the premier functionalist, remains in the fuzzy background. Returning in 1950 to his remarkable 1929 History, Boring could note that "Watson was a functionalist (with a small f) but he could not tolerate for long the requirement of the Chicago school that even the animal psychologist must take time to translate [sic] positively observed behavior into the vague terms of an inferred consciousness" (1950: 641). Indeed, with this not so subtle erasure of differences between pragmatism and positivism, Boring could conclude that "[operationism] was there all along," recognized well before Percy Bridgman and Vienna positivism as an "advance" by American psychologists (1950: 656).

With Watson's behaviorism, scientific psychology had not only expunged all talk of "consciousness," but indeed had become a technocratic science of prediction and control. Considering the stereotypes of American pragmatism, its talk of the "cash value" of ideas, and Dewey's association with Progressive political and social theory, it is easy to understand his taken-for-granted role in this development, especially when his 1896 essay, "The Reflex Arc Concept in Psychology" is taken, remarkably, to be "one of the most important arguments for the functional attitude toward the interactions (sic) between stimulus and response" (Hilgard 1987: 81) and, even more remarkably, when we 
notice that in 1943, this paper "was chosen as one of the most important articles ever published in Psychological Review" (Leahy 1992: 282).

\section{Dewey's 1896 Essay on the Reflex Arc}

But the critical point is the failure to recognize the philosophical background and fundamental point of Dewey's famous essay on the reflex arc. It is true and important to recognize that between perhaps 1891 and 1903, with the Studies in Logical Theory, Dewey had made a conversion to his distinctive version of naturalism. But it is equally true and important that this was a naturalism that carried a huge Hegelian residue. Flower and Murphey say it well:

It is almost as if Dewey held off from naturalism until he should be able to integrate with it those aspects of idealism which he regarded as philosophically important: the view of knowledge as organic and relational, the social character of both self and knowledge, the unifying and purposive character of judgment. Dewey could not bring together those features with naturalism as long as the dominant model of the latter was atomistic. (Flower \& Murphey 1977: 820)

This is was precisely the burden of the reflex arc essay. Dewey acknowledged that "the idea of a reflex arc has upon the whole come nearer to meeting the demand for a general working hypothesis than any other concept" (EW: 5: 96) and his essay is not intended "to make a plea for what it replaced." But the new account, best intentions notwithstanding, suffered from all the features of the older account. "The dualism between sensation and idea is repeated in the current dualism of peripheral and central structures and functions; the older dualism of body and soul finds a distinct echo in the current dualism of stimulus and response" (ibid.). Thus, "the sensory stimulus is one thing, the central activity, standing for the idea, is another thing, and the motor discharge, standing for the act proper, is a third." But if so, is it impossible to see how action can be thought-guided or how we can learn? Experience shows not only that we do, but also what is amiss: the reflex arc is not "a patchwork of disjointed parts, a mechanical conjunction of unallied processes." It was not to be understood "mechanically" but "functionally." Rather, it is "a comprehensive or organic unity" (97). Dewey could now reject mechanism and atomism from a fully naturalistic point of view.

While for Dewey intentionality is a fundamental feature of all learning, he surely has not given us any account that provides the mechanisms for this. It will surely be a messy psychology including as it does a revisioning of the role and relationships of all the critical elements. But it is a naturalistic program which rejects all the mainstream versions of psychology. ${ }^{15}$

\section{"Scientism" and "Scientific Psychology"}

In the ensuing years, "stimulus" will be employed to suit nearly any purpose, from a physical input or physiological event to, incoherently, "a situation or an involved object with meaning encrusted on it" (Boring 1929: 586). All of this, to be sure, was "scientific" defined exactly in positivist terms. Thus, propelled and legitimated by the wedding of traditional Humean empiricism and the extensionalist logic of Principia Mathematica, logical positivism could vindicate the so-called "Age of Theory." With "intervening variables" and "hypothetical constructs, S-R psychology could even offer gestures in the 
way of central processes. It seems unlikely that those who judged Dewey's reflex-arc essay to be one of "the most important articles ever published in Psychological Review" could have understood Dewey's paper. We can note also that Watson fully admitted being perplexed by Dewey. Although he had been drawn to Chicago to study with Dewey, in his autobiography Watson wrote: "I never knew what he was talking about then, and unfortunately for me, I still don't know" (cited by Fancher 1979: 316). Indeed, the example attests, by this time, to the hegemonic standing of logical empiricism among "scientific" true believers!

61 After the mid 1890s, Dewey wrote nearly nothing that could be said to find a place in the emerging discipline of American psychology. Several reviews give us some additional insight into why this was so. His 1898 review of Baldwin's Social and Ethical Interpretations of Mental Development, offers a critical distinction: between examining the individual from the standpoint of psychical process and determining what of this is social, and examining not the process but the content of the individual's experience to discover what this has in common with others (EW 5: 385-6). For Dewey, the first belongs to psychology, the second to sociology. Baldwin confuses these question because he falls into a trap: Both "the individual" and "the society" are taken as given. Accordingly, "when we want to know about the individual we are referred to society; when we want to know about society we are referred to the individual" (388).

Dewey should not have been disappointed. Indeed, just three years earlier, in a paper read at a joint session of the American Philosophical and American Psychological Associations on "The Standpoint and Method of Psychology," he expressed fears about the direction of "the behavioristic movement." It was quite one thing to throw out "consciousness" as private and open only to introspection. It was quite another thing to throw out "mind" in the sense just noted. "To conceive behavior exclusively in terms of the changes ongoing on within an organism physically separate in space from other organisms is to continue that conception of mind which Professor Perry has well termed, 'subcutaneous"' (MW: 7: 54). His criticisms paralleled those made against S-R psychology: "In so far as behaviorists tend to ignore the social qualities of behavior, they are perpetuating exactly the tradition against which they are nominally protesting" (54).

\section{Dewey and Academic Social Science}

63 Dewey said very little about the social sciences and although one finds throughout the corpus, references to science, one finds little in the way of a systematic account of science. Most of the terms descriptive of science and in general use were - and are vague and uncritically employed: for example, cause, law, theory, explanation and experimental method. Dewey, like most writers today, could take these terms for granted even if, as I would insist, one can get contradictory conceptions of science from different analyses of them. This unclarity should not surprise us. What we now think of as an important subdiscipline of philosophy, philosophy of science, emerged only in the 1950s and it is only in the 1970s that there has been a genuine competitor to the positivist interpretation of science.

Logic: The Theory of Inquiry, published in 1938, is surely the main exception to the overall absence of texts on Dewey's theory of science. What is there is very important, but there are many important questions which Dewey did not address and, typically, he does not 
make effort to place his work in the context of other writers on science, Vienna positivism, for example. When the Logic was published, as Ralph Sleeper has argued, it was both ignored and misunderstood, so thoroughgoing were entrenched assumptions about logic and science. Moreover, by this time, systematic misunderstanding of Dewey was also well-entrenched. Accordingly, it was not then, and is not now, a genuine competitor for the received views of logic and science.

\section{Dewey's Rejection of the Epistemological Problem} epistemological problem," the problem of justifying true belief. Dewey, following Peirce and James, rejected the assumptions which generated the problem, a defining feature of pragmatism. Thus, inquiry begins with genuine doubt and ends when doubt has been overcome. In every case, whether in the sciences or the problem solving of ordinary life, the settling of belief begins with a clear definition of the concrete problem, an assembling of all the materials, intellectual and material, and then action which either settles the doubt or does not. Dewey's philosophy is a praxis philosophy in just this sense. Failure to see this has misled many otherwise astute commentators. Dorothy Ross, for example, singles out Dewey's (1897) lecture, "The Significance of the Problem of Knowledge" as a critical intervention on the side of the technocrats. But this is far from being the case: Its thrust is against traditional foundationist epistemology: rationalist, sensationalist and Kantian. Dewey writes:

Knowledge can define the percept and elaborate the concept, but their union can be found only in action. The experimental method of modern science, its erection into the ultimate mode of verification, is simply this fact obtaining recognition. (EW 5: 21)

Contrary to the epistemologists, there is no problem of knowledge in general: philosophy is "not an original fountainhead of truth." And this means that for answers to questions about how knowledge is possible we need to look to psychology and social ethics "including in the latter term all the related concrete social sciences, so far as they may give guidance to conduct" (22). Dewey's project was to naturalize epistemology and moral theory.

The sociologist, like the psychologist, often presents himself as a camp follower of genuine science and philosophy, picking up scraps here and there and piecing them together in somewhat aimless fashion [...] But social ethics represents the attempt to translate philosophy from a general and therefore abstract method into a working and specific method; it is the change from inquiring into the nature of value in general to an inquiry of the particular values which ought to be realized in the life of everyone, and of the conditions which shall render possible this realization. (23)

This is a stunning research program for social science, stunningly ignored. We need to be clear about this. Dewey believed, rightly, that human sciences could help us to understand ourselves: how we think and inquire and why, when thinking and inquiry is successful, it is successful. They would give us insight into what were our genuine interests and purposes and their relations, and most obviously, they would give us an understanding of the obstacles in present arrangements that keep us from realizing our genuine interests and purposes. The human sciences would be a "social motor," emancipating in exactly the sense that they would clear away misconceptions about 
ourselves and our arrangements and empower us to reconstruct the social world more in accordance with our wants and aims.

Central to this project was the rejection of the bifurcation of fact and value, a further consequence of the mistaken assumptions that had generated "the epistemological problem." In his Logic, Dewey argued that "most current social inquiry" was marked by "the separation of theory and practice" (LW 12: 487). It is sound principle, Dewey says, that one should avoid making social judgments "on the ground of moral preconceptions, conceptions of what is right and wrong, vicious and virtuous" (489). But this is mistakenly converted to the principle that one should make no evaluations about ends. But "only recognition in both theory and practice that ends to be attained (ends-in-view) are of the nature of hypotheses and that hypotheses have to be formed and tested in strict correlativity with existential conditions as means, can alter current habits of dealing with social issues" (491).

Moreover, it is easy to assume that "the problems which exist are already definite in their main features." The result is that "methods for resolving problematic situations are proposed without any clear conception of the material in which projects are to be applied and to take effect," with often a worsening of the situation which generated the inquiry (LW 12: 487). The analogy between current modes of inquiry in social science and prescientific medicine was apt. As Dewey noted elsewhere, such practice was a combination of empiricism and quackery: Without analysis, symptoms were responded to in terms of handed down remedies. Of course, these sometimes worked. But as regards medicine at least, "it is now recognized that choice of remedial measures looking to restoration of health is haphazard until the conditions which constitute the trouble or disease have been determined as completely and accurately as possible" (488).

The self-imposed constraints of "allegedly scientific social inquiry" also explains the positivist penchant for "fact-gathering." Dewey had attacked this idea in his 1931 essay, "Social Science and Social Control." Dewey offered that "the existing limitations of "social science' (Dewey's quotation marks) are due mainly to unreasoning devotion to physical science as a model, and to a misconception of physical science at that" (LW 6: 64). In the Logic, Dewey held that methods adopted "in the professed name of social science" are merely the form of genuine science since they fail "to observe the logical conditions which in physical science give the techniques of observing and measuring their standing and force" (LW 12: 492). There are many places where Dewey assessed current social science as deficient. In this essay (as in the Logic), Dewey held: "[T]he facts of social 'factfinding' remain a miscellaneous pile of meaningless items." "Since their connections with human wants and their effect on human values are neglected, there is nothing which binds them together into an intelligible whole" (LW 6: 65).

71 Indeed, in a related section of the Logic, Dewey developed an argument that C. W. Mills will pick up in his 1959 Sociological Imagination. Dewey saw two one-sided distortions. The "positivist" school (his term!) singlemindedly directs itself as "fact-finding" - what Mills had called "abstracted empiricism." But the opposing tendency "places its entire emphasis on conceptions" (LW 12: 497) - what Mills called "Grand Theory." As with Mills, "facts are subsumed directly under 'principles,' the latter being regarded as fixed norms that decide the legitimacy or illegitimacy of existing phenomena and that prescribe the end toward which endeavor should be directed" (497). 


\section{Instrumentalism and Science}

Dewey's commitments to scientific method, his persistent attacks on inquiry detached from human concerns and his extensive use of technological metaphors have caused enormous confusion, but Hickman wisely glosses Dewey's "instrumentalism" by arguing that "Dewey goes beyond theory and beyond praxis to production: his concern is with the making and testing of new entities including extra-organic tools as well as goals and ideals" (15). "Science" in this sense is a more refined and developed form of all inquiry. Thus, in the Logic, Dewey insists that "there is no sharp dividing line between common sense and science. "Control" - as Hickman says, a synonym for knowledge - does not refer to the subordination or domination of something. Rather, as Dewey makes clear enough, "control" refers to our capacity to apply intelligence successfully: to produce, adapt, adjust, accommodate, achieve, institute, identify, order, discriminate, and to "resolve" problems in many other sorts of ways. "Control" has been achieved when the problem which generated inquiry has been resolved.

It is in this sense, also, that "practical" must be understood. These "technical processes and instrumentalities" then become "the background of materials and operations which we term science" (LW 12: 77). And, indeed,

Genuine scientific knowledge revived when inquiry adopted as part of its own procedure and for its own purpose the previously disregarded instrumentalities and procedures of productive workers. This adoption is the radical characteristic of the experimental method of science. (LW 12: 99, 388-9)

But this does entail a collapse of science into technology in the sense that all inquiry has some immediate practical aim and surely not in the sense that we can and should seek to dominate nature. All knowing is technological in the sense that if the problematic situation is to be brought under "control," language, mathematics and/or artifacts of various kinds are required. Indeed, more generally, this is consequence of Dewey's attack on the "spectator theory of knowledge." But the difference between science and common sense is exactly that while commonsense inquiry "occurs for the sake of settlement of some issue of use and enjoyment," scientific inquiry occurs "for its own sake" (LW 12: 66-7.)

Dewey's position here is almost always overlooked. Dewey did not reject the (Greek) idea that inquiry could be aimed solely at understanding. He rejected the bifurcation of theory and practice, the idea that one could understand anything without "tools" and without "experimental operations, involving definite techniques" (LW 12: 151, 420, 455). We need here to notice that the continuity between science and commonsense creates a very special burden for social science. Cultural conditions impact all inquiry - a critical point for an anti-positivist sociology of science, but because "the physical" is "relatively independent of social issues," "the influence of cultural conditions" is "indirect." For example, "it is not possible [...] to separate nineteenth century devotion to exclusively mechanical conceptions from the needs of industry of that period." In social science, by contrast, "prejudices of race, nationality, class and sect play such an important role that their influence is seen by any observer of the field" (LW 12: 482). For Dewey, as for contemporary anti-positivists, this called for a self-conscience reflexivity.

European Journal of Pragmatism and American Philosophy, III-2 | 2011 


\section{Scientific Laws and Causality}

76

Critical to any understanding of science is the conception of law and causality. First, Dewey rejected the most characteristic, even defining features of empiricist philosophy of science: that "scientific laws are formulations of uniform and unconditional sequences of events," and that causality must be defined in terms of such sequences (LW 12: 437). Of all the doctrines which currently inform mainstream social science, these are surely the most pernicious. Once accepted, we are committed to an event ontology and a regularity determinist view of the universe: Whenever this, then that. It is then also easy to assume a covering law model of explanation, and thus to hold also that prediction and explanation are symmetrical. One final consequence is the inability to conceptualize agency: the fact that persons make things happen. But as Dewey rightly sees, "there are no such things as uniform sequences of events" (LW 12: 445). affinities and repulsions to other events" (LW 1: 162). These "selective biases," he says, define their "essence," a term Dewey used without prejudicing his fully processual view of the universe. But since on a realist view, the "things" of the universe are always related to other "things," outcomes are never guaranteed. Thus, "iron as such exhibits characteristics of bias or selective reactions," but "iron as a genuine constituent of an organized body acts so as to end to maintain the type of activity of the organism to which it belongs" (195). In a living organism, it functions not to produce iron-oxide - as it would in a hinge - but to contribute to metabolism.

Moreover such moves are quite consistent with his idea that commonsense inquiry is continuous with advanced science. Dewey gives some examples: "A good rain will cause the seeds that have been planted to grow." The expectations are "explained" by the unscientific person by attributing a power to rain. The empiricist disallows this, but content with an effort to establish the validity of the expectations, he does not seek to understand the "power." The scientific problem is not, as positivists would have it, to close the system in order to make better predictions. Rather the scientific problem is to identify what is about the nature of water and of seeds such that a good rain will (ceteris paribus) cause the seeds to grow. One needs a theory about pertinent causal mechanisms, not a better analysis of the "variables."

For example, Ross (1991: 253) holds that Dewey's "Psychology and Social Practice" is another place where he endorses technocracy. Dewey argues that the teacher has a psychological theory, like it or not. "Teachers tell you that a child is careless or inattentive in the same final way that they would tell you that a piece of paper is white." But, insists Dewey, it is only through some recognition of attention as a mechanism, some awareness of the interplay of sensations, images and motor impulses which constitute it as an objective fact that the teacher can deal effectively with attention as a function" (139).

Dewey's point is exactly that unless teachers have an understanding of the student as a psycho-social being, all their efforts are bound to be misdirected, ineffective, even destructive. It is only by understanding the psychological "mechanisms" of attention, memory, cognition and judgment and the social "mechanisms" implicated in all experience and behavior that the teacher can cultivate the powers of the student. This is for Dewey a research program to be satisfied. We are, he says, discussing the question of

European Journal of Pragmatism and American Philosophy, III-2 | 2011 
the role of psychological science in education only because "we have as yet made so little headway" (144).

Dewey's use of the term "mechanisms" here is notable and suggests how far he is from a regularity determinist view. This is made even clearer in a 1918 essay entitled "A New Social Science," one of the very few places where Dewey explicitly discusses social science. Dewey argues against the idea, inherited from Comte and Spencer - and still very much current - that "the existing social order is the product of natural laws which are expounded in a rational, scientific way" (MW 11: 89). Indeed, very much along the lines of Weber's criticism of positivist social science, any science which pretends to be more than a description of the particular forces which are at work and a descriptive tracing of the particular consequences which they produce, which pretends to discover basic principles to which social things conform, and inherent laws which 'explain' them is, I repeat, sheer mythology (90).

Dewey acknowledged radical contingency in the universe, a universe which was both "precarious and stable." There were uniformities - a consequence of "selective biases" and there were plenty of surprises, a consequence of the open systematic character of the world. But such a metaphysic calls for a historical and concrete social science. The "description of particular forces" at work are the analogue of the "selective biases" discoverable by physical science. The "particular consequences" which they produce are not guaranteed in advance because there is always the fact of agency working with materials at hand. There are no "general laws" under which we can subsume and thereby explain wars, revolutions or, for that matter, hurricanes or the genesis of a species. Indeed, all concrete events are the product of many causes working conjointly (see Manicas 2006, Chapter 5).

Dewey concludes this brief but rich essay by remarking that "there is [...] an immense amount of empirical subject-matter contained within the confines of existing social sciences. The only trouble is that it has been 'framed up' and betrayed by its mythical and apologetic setting" (MW 11: 91). He does not, unfortunately, elaborate on this very pregnant idea; but there is little doubt that it regards the guiding principles of positivist social science.

The example raises, as well, the question of the relation of democracy to social scientific knowledge. For the technocrats, one "controls" the conditions and gets "predictable results." More, because "experts" have knowledge which the "masses" lack, democracy must give way.

\section{Social Science and Democracy}

It is easy enough to establish that World War I had a tremendous impact on Dewey and that one of the consequences was his readiness to believe that the war had brought forward "the more conscious and extensive use of science for communal purposes." It had "made it customary to utilize collective knowledge and skill of scientific experts of all kinds, organizing them for community ends." The warfare state, remarkably, had laid the foundations for the Nationalist Liberalism which became the political agenda of Dewey's associates at the The New Republic. But when Walter Lippmann, already persuaded of a technocratic version of social control, published his Phantom Public in 1925, Dewey finally came to grips with the problem of scientific knowledge and democracy. ${ }^{16}$ 
In The Public and Its Problems (1927), Dewey agreed that there were a host of "technical" questions which could be answered by "experts": "sanitation, public health, healthful and adequate housing, transportation, planning of cities, regulation and distribution of immigrants, selection and management of personnel, right methods of instruction and preparation of competent teachers, scientific adjustment of taxation, efficient management of funds and so on" (LW 2: 313). But the idea that such knowledge was sufficient was profoundly in error. Those who hold to such views "ignore forces which have to be composed and resolved before technical and specialized action can come into play" (LW 2: 313). The problem is deep: "It is in the first instance the search for conditions under which the Great Society may become the Great Community" (327). The public is lost, eclipsed, inchoate, bewildered, caught in a drift which it cannot grasp and therefore cannot over-come. Indeed, "the prime condition of a democratically organized public is a kind of knowledge and insight which does not exist" (339). Citizens needed to understand what was happening and why. Some technical knowledge was needed, to be sure, but in the absence of a widely shared understanding of the "forces" at work, no democratic public could emerge.

Dewey is not as radical as he might be in assigning the causes of this. Put aside here the problems of distributing "the kind of knowledge which does not exist," for example, problems of the corporate control of mass communication, and concentrate here on the role of the social sciences themselves. In particular, while he acknowledges the limits of the special sciences in generating such knowledge, he does not seem to see that they contribute mightily to the mystification of what needs to be known. Instead of illuminating and emancipating, too much contemporary social science obscures and misleads.

Dewey gets his hands on some of the reasons for this. He notes that the "backwardness of social knowledge is marked in its division into independent and insulated branches of learning" (171). This point, versus disciplinary social science is never noticed and is critical. ${ }^{17}$ But this is more than a "mark" of its "backwardness": It guarantees backwardness. It is not merely, as he says, that there is lacking "continuous crossfertilization," but that fragmentation prevents us from grasping causes and connections.

Dewey notes also that specialized knowledge aims to be "abstract" which practically means that "it is not conceived in terms of its bearing on human life" (171). Plainly, the commitment to value-neutrality requires this. The upshot, of course, is not valueneutrality, but as Veblen insisted, scientific legitimation of "usages and conventions that have by habit become embedded in the received scheme of use and wont, and so have been found to be good and right." Social science happily conspires in persuading us that the poor have only themselves to blame.

Dewey argues forcefully that what counts as "news" in our daily papers is rendered completely unintelligible in terms of its connections but fails to argue that this tendency is reinforced by "fact-gathering" social science. He is correct that "a genuine social science would manifest its reality in the daily press, while learned books and articles supply and polish tools of inquiry" (347), but of course, it is precisely because "we" are not journalists but "social scientists" that we write jargonized "learned" books and articles. As Lynd said, we are either "scholars" or "technicians" - working for whoever will pay the bill. 
91 Finally, for all of Dewey's interest in education, he makes no mention of the disastrous consequences of current patterns of education in the social sciences. Instead of cultivating what Mills called "the sociological imagination," we offer students textbooks which guarantee disciplinary fragmentation, empty abstractions and uncritical thought. Instead of seeking causes and insisting on making connections, we require "disciplinary" integrity. Instead of raising questions about "habits embedded in the received scheme of things," we seek "relations of variables."

Dewey was surely on the right track when, as early as his essay on Renan, he offered some reasons for these patterns of ideology and disinformation. He then wrote that we do not yet appreciate "the dead weight of class interest which resists all attempts of science to take practical form and become a social motor" (EW 4: 17). I conclude by saying that we still do not - itself a function of the failure of the present practices of the social sciences.

\section{BIBLIOGRAPHY}

BORING E.G., (1929), A History of Experimental Psychology, London, Century Co.

BORING E. G., (1950), A History of Experimental Psychology, New York, Appleton- Century-Crofts.

DEWEY J., (1969-72), The Early Works, 5 Volumes, Carbondale, Southern Illinois Press.

DEWEY J., (1976-83), The Middle Works, 15 Volumes, Carbondale, Southern Illinois Press.

DEWEY J., (1981-90), The Later Works, 17 Volumes, Carbondale, Southern Illinois Press.

DEWEY J., (1954 [1927]), The Public and Its Problems, Chicago, Swallow Press.

DUHEM P., (1906), La théorie physique, son object, sa structure, translated as The Aim and Structure of Physical Theory, Princeton University Press, 1954.

FANCHER R. E., (1979), Pioneers of Psychology, New York, W. W. Norton.

FLOWER E. \& M. MURPHEY, (1977), A History of Philosophy in America, Two Volumes, New York, G. P. Putnams Sons.

HeLmholtz H., (1971), Selected Writings, Russell Kahl (ed.), Middleton, Conn., Wesleyan University Press.

HICKMAN L., (1990), John Dewey's Pragmatic Philosophy, Bloomington, University of Indiana Press.

HILGARD E. R., (1987), Psychology in America: A Historical Survey, San Diego, Harcourt Brace Jovanovich.

HOLLINGER D. A., (1985), In the American Province, Bloomington, University of Indiana Press.

JAMEs W., (1978), "The Knowing of Things Together" [1894], in Essays in Philosophy, Works, Cambridge (Ma.), Harvard University Press.

JAMES W., (1978), "The Sentiment of Rationalty," in Essays. 
JAMES W., (1981), Principles of Psychology, Two Volumes, Cambridge (Ma.), Harvard University

Press.

LEAHY T. H., (1992), A History of Psychology, 3rd Edition, Englewood Cliffs (NJ.), Prentice-Hall.

PEIRCE C. S., (1950), Values in a Universe of Chance, P. P. Weiner (ed.), New York, Doubleday. All quotations from Peirce are from this Volume.

SMELSER N., (1986), Behavioral and Social Sciences: Fifty Years of Discovery, Washington (D.C.), National Academy Press.

somit A. \& J. TANnenhaus, (1967), The Development of American Political Science from Burgess to Behaviorism, Boston, Allyn and Bacon.

VEBLEN T., (1957 [1906]), The Higher Learning in America, New York, Sagamore.

VEBLEN T., (1961), The Place of Science in Modern Civilization and Other Essays, New York, Russell and Russell.

\section{NOTES}

1. See Dorothy Ross, The Origins of American Social Science (Cambridge, Cambridge University Press, 1991). She writes: "[Scientism] was the result of a long-standing commitment perennially deferred, an effort to make good on the positivist claim that only natural science provided certain knowledge and conferred the power of prediction and control. With science now defined by its method, scientism demanded that the requirements of natural scientific method dominate the practice of social science" (Ross 1991: 390). She seems wrongly to assume that the positivists provide a generally correct understanding of natural science. As regards social science, Ross seems to favor interpretative models "available in history and cultural anthropology" or "the generalizing and interpretative model offered by Max Weber" (Ross 1991: 473). I argued in A History and Philosophy of the Social Sciences (Oxford, Basil Blackwell, 1987) and in A Realist Philosophy of Social Science (Cambridge, Cambridge University Press, 2006) that there was a third, critical realist alternative. I suggest in what follows that James and Dewey seem to have stumbled toward this alternative, ambiguously realist, and emphatically neither positivist nor "interpretative."

2. By the 1970s, every pillar of the positivist consensus among philosophers of science had come apart. See Manicas, A History and Philosophy of the Social Sciences, Chapter 12 for a summary. However, the defining features of this consensus, for example, the positivist account of explanation and causality, has, by virtue of institutionally inertia, hardly touched American social scientists. For evidence, see almost any textbook in social science. Indeed, contemporary economics, often considered the most mature of social sciences, is also the most unapologetically positivist.

3. Especially with the work of R.W. Sleeper, The Necessity of Pragmatism (New Haven, Yale University Press, 1986) and Tom Burke, Dewey's New Logic: A Reply to Russell (Chicago, University of Chicago Press, 1994), we are just now beginning to get clear about the central role of his Logic: The Theory of Inquiry - even if the two most recent full-length accounts, one by an historian, Robert Westbrook (John Dewey and American Pragmatism, Ithaca, Cornell University Press, 1991), the other by a philosopher (Alan Ryan, John Dewey and the High Time of Liberalism, New York, Norton, 1997), say nothing of any use about how this bears on Dewey's conception of science, but especially social science. As regard pragmatism and post-modernism, see, for example, "A Social Theory Dialogue between Peter Manicas and Patrick Baert," 7 (2), 62-101, 2008.

4. J. Passmore, A Hundred Years of Philosophy, Rev. Ed., (New York, Basic Books, 1966), Chapter 14. 
5. P. Duhem, The Aim and Structure of Physical Theory [1906], (Princeton, Princeton University Press, 1954), 7, 19. Anti-positivists included, prominently, Hermann von Helmholtz, James Clerk Maxwell and J. J. Thomson. For example, Helmholtz insisted that "the word Ursache (which I use here precisely and literally) means that existing something [Bestehende] which lies hidden behind the changes we perceive. It is the hidden but continually existent basis of phenomena" (Helmholtz 1971: 521). See Peirce and James, below.

6. Much more complete sketches may be found in my A History and Philosophy of the Social Sciences and "The Social Science Disciplines: The American Model," in B. Wittrock \& P. Wagner (eds.), Yearbook Sociology of the Sciences (Dordrecht, Reidel, 1990). A still fuller account is to be found in Ross, Origins of American Social Science. For discussion of the different historical experiences of European social science, see Wagner, Peter, Wittrock. Bjorn, \& Richard Whitely (eds.), Discourses on Society: The Shaping of the Social Science Disciplines, Sociology of the Science Year-book, XV, (Dordrecht, Kluwer Academic Publishers, 1991), especially, perhaps, the fine summary essay by Wagner and Wittrock, "States, Institutions, Discourses: A Comparative Perspective on the Structuration of the Social Sciences," in Wagner et al. (ibid.), 331-58. The volume treats nineteenth century European differences well, but no effort was made to examine traditions elsewhere. Historically rooted differences remain in contemporary practices in European social science, e.g., in the absence of a separate faculty for the social sciences in France, or in the French admixture of neo- classical theory and engineering in economic science. A license degree in economics was not created until 1958.

7. Lenin clearly saw that the issues were important. In his too little studied Materialism and Empirio-Criticism (1908) (Moscow, Progress Publishers), Lenin defended Engels's materialism against those "bold warriors, who proudly allude to the 'modern theory of knowledge,' 'recent philosophy' (or 'recent positivism'), the 'philosophy of the natural sciences' or even more boldly, 'the philosophy of natural science of the twentieth century"' (Empirio-Criticism: 7). Dilthey rejected totally "the philosophy of the natural sciences as pertinent for the human sciences." Weber, of course, held that the need for verstehen critically distinguished the human or cultural sciences, but held also that these sciences aimed at causal explanation, understood in antiHumean terms. See Manicas, A Realist Philosophy of Science (Cambridge, Cambridge University Press, 2006), Chapter 5.

8. See Wittrock, Bjorn, "The Modern University: The Three Transformations," in Rothblatt, Sheldon \& Bjorn Wittrock (eds.), The European and American University Since 1800: Historical and Sociological Essays, Cambridge, Cambridge University Press, (1993).

9. Bledstein, Burton. The Culture of Professionalism: The Middle Class and the Development of Higher Education in America, New York, W. W. Norton, (1976); See also, Hofstader Richard, The Age of Reform, New York, Knopf, (1955).

10. He explicitly attacked Karl Pearson and the anti-metaphysicians: "Those eminent authorities who speak for a colorless mathematical formulation invariably and necessarily fall back on the (essentially metaphysical) preconception of causation as soon as they go into the actual work of scientific inquiry" (Veblen 1961: 15).

11. Cited from Neil J. Smelzer (1986: 27).

12. For a fuller account, see Manicas, Journal for the Theory of Social Behavior, 32 (3) (September, 2002). Owen Flanagan Jr. has provided a reading of Principles along the lines of an non-reductive neuropsychology in his The Science of the Mind, Cambridge, MIT press, (1984).

13. The failure to see the novelty and power of the philosophy of science found in his Principles is partly explained by his self criticism of psychology as a science (below), and, subsequently, by the overwhelming attention given his later philosophy, especially, of course, his popular Pragmatism and Essays in Radical Empiricism.

14. Letter to Henry Holt, his publisher, May 1990, quoted from Ralph Barton Perry, The Thought and Character of William James, two vols, Boston, Little, Brown, (1935). 
15. In "John Dewey and American Psychology," I argue that Dewey's reflex arc essay is the point of departure of a unique approach to what I term an "ecological psychology." It is another unfulfilled Deweyan program which anticipates fatal criticisms of much recent "cognitive psychology."

16. See my War and Democracy, Oxford, Blackwell, (1989, Chapter 8).

17. See also Logic (LW 12: 501-2).

\section{AUTHOR}

\section{PETER MANICAS}

University of Hawai'i at Manoa

manicas[at]hawaii.edu 